\title{
Delayed reconstruction of mangled lower extremities: soft tissue management
}

\section{Ezilmiş alt ekstremitenin gecikmiş rekonstrüksiyonu: Yumuşak doku tedavisi}

\author{
Yiğit Özer Tiftikcioğlu, ${ }^{1}$ Burak Sercan Erçin, ${ }^{1}$ Mehmet Erdem, ${ }^{1}$ Ahmet Biçere, ${ }^{1}$ Nadir Özkayın, ${ }^{2}$ Cüneyt Özek ${ }^{1}$ \\ ${ }^{1}$ Ege Üniversitesi Tip Fakültesi Plastik, Rekonstrüktif ve Estetik Cerrahi Anabilim Dal, İzmir, Turkey \\ ${ }^{2}$ Ege Üniversitesi Tip Fakültesi Ortopedi ve Travmatoloji Anabilim Dal, İzmir, Turkey
}

\begin{abstract}
Objectives: This study aims to propose a new, practical and versatile algorithm for the management of traumatic lower limb soft tissue wounds for patients who did not undergo early reconstruction.

Materials and methods: A total of 81 patients (54 males, 27 females; mean age 37.1 years; range 11 to 64 years) managed due to complex lower limb injuries at our institution between January 2008 and December 2012 were analyzed retrospectively in this study. Age and gender of the patients, type of trauma, utilization of vacuum assisted closure (VAC) therapy, time lapse between injury and definitive reconstruction, as well as major and minor complications were recorded and analyzed.

Results: The average time from injury to definitive reconstruction procedure was 20.4 days. Sixty two percent of the patients were treated with VAC therapy before the definitive reconstruction. Hospital stay ranged from 5 to 100 days, with a mean stay of 42.7 days. Thirteen and a half percent of patients had a soft-tissue defect in the proximal one third, $33.3 \%$ in the middle one third and $53.2 \%$ in the distal one third of the leg. Overall, the rate of complications was $12.3 \%$.

Conclusion: Based on the findings of this study, we believe that post-traumatic lower extremity reconstruction may safely be performed when the wound is adequately debrided and when the surgeon follows the basic principles of reconstructive surgery even in a sub-acute or delayed fashion. We also proposed a clinical algorithm regarding the reconstructive options.

Keywords: Debridement; lower limb; microsurgery; soft-tissue reconstruction; vacuum assisted closure.
\end{abstract}

ÖZ

Amaç: Bu çalışma erken rekonstrüksiyon yapılmayan hastalarda travmatik alt ekstremite yumuşak doku yaralarının tedavisi için yeni, pratik ve çok yönlü bir algoritma önermektedir.

Gereç ve yöntemler: Bu çalışmada Ocak 2008 ile Aralık 2012 tarihleri arasında kompleks alt ekstremite yaralanması nedeni ile kliniğimizde tedavi edilen toplam 81 hasta (54 erkek, 27 kadın; ort. yaş 37.1 yıl; dağılım 11-64 yıl) geriye dönük olarak incelendi. Hastaların yaş ve cinsiyeti, travma tipi, vakum yardımlı kapama (VAC) tedavisinin kullanımı, yaralanma ile definitif rekonstrüksiyon arasındaki zaman aşımı ve ayrıca majör ve minör komplikasyonlar kaydedildi ve analiz edildi.

Bulgular: Yaralanmadan definitif rekonstrüksiyon işlemine kadar geçen ortalama süre 20.4 gündü. Definitif rekonstrüksiyon yapılmadan önce hastaların \%62'ine VAC tedavisi uygulandı. Hastanede kalış süresi ortalama 5 ile 100 gün, ortalama 42.7 gün idi. Hastaların \%13.5'inin bacağın proksimal $1 / 3$ 'ünde, $\% 33.3^{\prime}$ ünün orta $1 / 3$ 'ünde ve $\% 53.2$ 'sinin distal $1 / 3$ 'ünde yumuşak doku defekti vardı. Genel olarak komplikasyon oranı \%12.3 idi.

Sonuç: Bu çalışmanın bulgularına dayanarak, post-travmatik alt ekstremite rekonstrüksiyonu, yaranın yeterince debride edilmesi ve cerrahın rekonstrüktif cerrahinin temel prensiplerini subakut veya gecikmiş bir şekilde izlediği durumlarda dahi güvenli bir şekilde uygulanabilir. Ayrıca rekonstrüktif seçeneklerle ilgili olarak klinik bir algoritma önerilmiştir.

Anahtar sözcükler: Debridman; alt ekstremite; mikrocerrahi; yumuşak doku rekonstrüksiyonu; vakum yardımlı kapatma.

The term 'mangled' describes an injury caused by crushing, which results in an unrecognizable limb; in essence, there are two treatment options for mangled extremities: amputation or salvage reconstruction. The definition of a 'mangled' lower limb however, is simplified to a lower 
extremity with an injury to at least two or three out of four cardinal structures (soft tissue, bone, nerves and vessels). ${ }^{[1]}$

Reconstruction of a severely injured lower limb poses a significant challenge to trauma surgeons as well as reconstructive surgeons. Since not only the complexity of the original injury but also any subsequent complications may result in amputations. Recently however, advances made in reconstructive techniques have made it possible to salvage limbs that would have been amputated in the past. With a growing body of experience dealing with these injuries from World War II, to the Korean and Vietnam Wars, and more recently the conflicts in the Middle East, progress has been clearly made and decreased amputation rates for mangled limbs (from 72 to $13-20 \%$ to less than $10 \%$, respectively) has occurred. ${ }^{[2]}$ While early reconstruction of soft tissue in mangled lower extremity remains the gold standard treatment modality, ${ }^{[1,3]}$ many patients miss the opportunity for an early reconstruction due to various reasons such as concomitant injuries or medical problems.

The aim of this study, which was based on our experience, is to help by proposing new, practical and versatile algorithms for management of traumatic lower limb soft tissue wounds for patients who missed the opportunity to undergo early reconstruction.

\section{MATERIALS AND METHODS}

In this retrospective study, patients admitted between January 2008 and December 2012 with injuries around and below the knee joint were rendered eligible to participate. Patients who moved out of our area and thusly were lost to follow up and patients with incomplete data were excluded. Overall, 81 posttraumatic lower limb reconstructions met the inclusion criteria and formed the basis of this study. Soft tissue defects were included in this study regardless of vessel or nerve damage. All cases were operated on and followed up by close cooperation of orthopedic trauma and plastic surgeons. Patients were admitted in sub acute or chronic stage in terms of their treatment for various reasons. The study protocol was approved by the Medical Faculty of Ege University Ethics Committee. A written informed consent was obtained from each patient.
The study was conducted in accordance with the principles of the Declaration of Helsinki.

Reconstructive approach was structured according to the location of the soft tissue defect regardless of the fracture location. The locations may be listed as: a) knee and the proximal one third of the leg; b) middle one third of the leg, and c) distal one third of the leg and foot.

Fracture classification, type of trauma sustained, utilization of vacuum assisted closure (VAC) therapy, the period between injury and definitive reconstruction, flap necrosis and rate of osteomyelitis and nonunion were recorded.

Bone fixation was performed by external fixator, intramedullary nail, plate or Kirchner wiring. Age and gender of cases, type of trauma, utilization of VAC therapy, time elapsed between injury and definitive reconstruction, minor and major complications have been recorded. All patients have been examined with a computed tomography (CT) angiography preoperatively for vascular patency. A radical debridement was performed perioperatively for all cases with close collaboration between plastic surgeons and orthopedic surgeons.

\section{RESULTS}

Out of 119 patients, 81 met the inclusion criteria. Sixty-seven percent of cases were men. Mean age of patients was 37.1 years (range 9-64). Mean follow-up period was 35 weeks (range 21-83 weeks). Seventy-five percent of patients $(n=60)$ had concurrent injuries. Forty-one percent of them $(n=25)$ had multiple trauma, $30 \%$ of them $(n=18)$ had intraabdominal hemorrhage $20 \%$ of them $(n=12)$ had intracranial hemorrhage and $9 \%(n=5)$ had undefined comorbidities.

The patients in the study could be categorized within two groups as; group 1: severely injured multitrauma patients, who had concomitant medical problems or need complex reconstruction and group 2: a second group of patients were the ones who subsequently became open fracture patients secondary to complications leading to soft tissue necrosis (Fractures of patients were shown in Table 1).

Forty-five patients' fractures were fixated with external fixators. Plates were used for 20 patients 
Table 1. AO fracture classification of cases

\begin{tabular}{lcc}
\hline & \multicolumn{2}{c}{ Patients } \\
\cline { 2 - 3 } Fracture & $\mathrm{n}$ & $\%$ \\
\hline $41-\mathrm{A} 1$ & 7 & 8 \\
$41-\mathrm{B} 1$ & 8 & 10 \\
$41-\mathrm{C} 1$ & 6 & 7 \\
$41-\mathrm{C} 2$ & 8 & 10 \\
$41-\mathrm{C} 3$ & 12 & 15 \\
$42-\mathrm{C} 1$ & 12 & 15 \\
$42-\mathrm{C} 2$ & 6 & 7 \\
$42-\mathrm{C} 3$ & 17 & 21 \\
Unclassified* & 5 & 6 \\
\hline AO: Arbeitsgemeinschaft für & \multicolumn{2}{c}{ Osteosynthesefragen; } \\
* Unclassified fractures were & recorded in Gustillo \\
classification. & & \multicolumn{3}{c}{}
\end{tabular}

and intramedullary nails applied for 16 cases. Kirschner wires were applied for five patients.

The mean time from injury to definitive reconstruction procedure was 20.4 days. (range 5-53 days). Sixty-two percent of patients were treated with VAC therapy before definitive reconstruction. Hospital stays ranged from 5 to 100 days, with a mean stay of 42.7 days $13.5 \%$ of patients had soft-tissue defects in proximal one third, $33.3 \%$ in middle one third and $53.2 \%$ in distal one third lower limb.

Reconstructive approach based on localization of injury was as follows;

\section{Proximal lower limb}

Out of 11 patients in this group, eight were treated with VAC dressing initially. A pedicled gastrocnemius flap was performed for nine of 11 patients. One free latissimus dorsi flap was employed for an exposed knee prosthesis. No complications have been encountered in this region during the mean follow-up period of 32.3 weeks.

\section{Middle lower limb}

Out of 27 patients, an initial VAC therapy was used for 17. Seven free latissimus dorsi flaps, two free anterolateral thigh flaps, four pedicled propeller perforator flaps, two soleal flaps, and four sural flaps were employed for soft tissue reconstruction. Postoperative complications were seen in four of 27 patients (14.8\%). One patient had chronic osteomyelitis that was treated with antibiotic therapy. Two cases of wound dehiscences and one partial necrosis were treated with daily dressing changes. One bony non-union case was revised during the follow-up period.

\section{Distal lower limb}

Forty-three patients in this group were treated with 38 flaps. Eighty-nine percent of flaps were utilized in free fashion (34/38). Thirteen percent of patients had complications such as flap necrosis, osteomyelitis and nonunion.

One pedicled sural flap used to cover a heel defect was lost completely. Then the defect was covered with a free anterolateral thigh flap. One free latissimus dorsi flap developed a venous insufficiency treated with revision of the venous anastomosis promptly. Two patients had chronic osteomyelitis that subsided with antibiotics. Two bony non-unions were revised by orthopedic surgeons. No amputations were performed on any of the patients.

\section{DISCUSSION}

\section{Timing of wound closure}

Timing of optimal wound closure after crush injury of lower limb has been an area of constant debate. Early closure with a well vascularized tissue has long been advocated by many authors. ${ }^{[3,4]}$

Godina was among the first to prove the value of early reconstruction of complex trauma in the lower limb. ${ }^{[3]}$ Many authors reported better results with early soft tissue reconstruction. However, the term 'early' is vague. Byrd et al. ${ }^{[5]}$ performed definitive reconstruction in the first five days to evaluate the benefit of muscle flaps in management of open tibia fractures. No non-unions or chronic infection cases were reported. Yaremchuk et al. ${ }^{[6]}$ performed 22 reconstruction cases at an mean of 17 days after injury with one flap loss and hence suggested performing definitive closure within the first 7-14 days after injury. Francel et al. ${ }^{[7]}$ reported successful free flap transfers for reconstruction of open tibial fractures that were performed during the first 15 days after injury with a 3.6\% ratio of major complications. Considerable amount of patients are being referred to the main trauma centers later than the first 72 hours of injury. In addition, some patients may have to be delayed due to multiple comorbidities or organizational problems. ${ }^{[8]}$

Another tool for soft tissue management, VAC therapy + delayed flap reconstruction has been emphasized by Hau et al. ${ }^{[9]}$ They hypothesized 
that VAC may help to reduce the flap size or a necessity for a flap. Nonetheless, he noted that long periods of VAC usage for open tibial fractures would lead to major complications.

The preferred approach in our institution is early soft tissue coverage. However, in this series of patients an opportunity for early reconstruction was missed for various reasons. Therefore a meticulous management plan was employed for those delayed cases which may be the key for better overall success rates.

\section{Mode of treatment}

Early debridement of avascular tissue is the most important issue in the management of the crushed lower limb. ${ }^{[10]}$ Removal of all foreign bodies and necrotic debris is the aim of debridement. Appropriate debridement not only supports the phagocytic activity, but also reduces the probability of tissue hypoxia and infection..$^{[1]}$
The earlier the debridement is done, the more the cellular mechanisms are promoted.

Depending on the nature of the injury, if the surgeon is not sure about the adequacy of debridement, a second look debridement procedure may be required after 48-72 hours (Figure 1). ${ }^{[3,4,10]}$ The most important part of soft tissue debridement is debridement of devitalized muscles. All muscle of suspicious vitality should be removed appropriately. Inadequate debridement of avascular muscle can even risk patient's life in a short period of time.

\section{Reconstruction}

Lately VAC has gained popularity in wound management. DeFranzo et al. ${ }^{[12]}$ have showed its advantages in lower extremity injuries. Parrett et al. ${ }^{[13]}$ have reported that VAC therapy had reduced the need for flap reconstruction as well. Vacuum assisted closure treatment

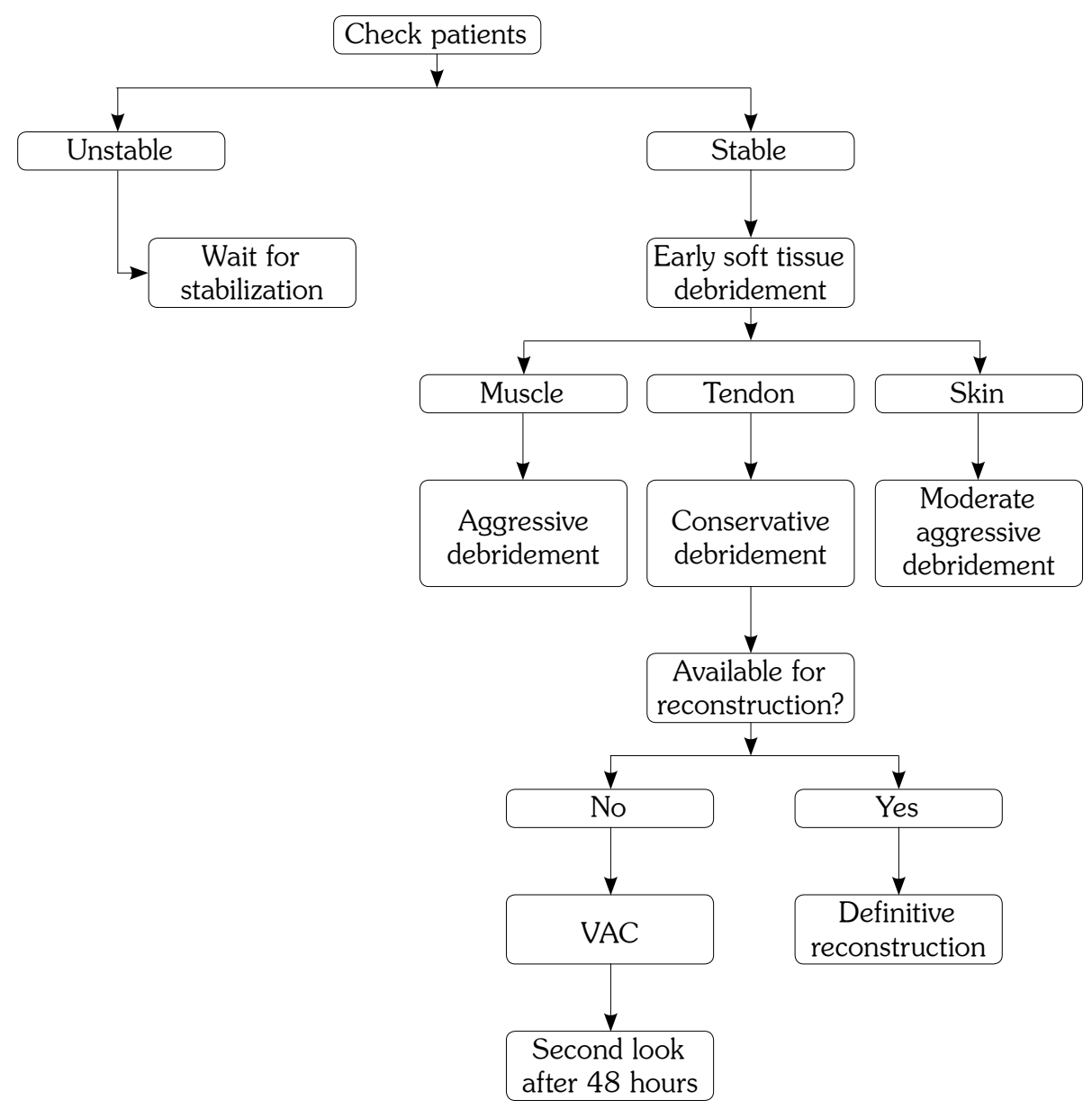

Figure 1. Our algorithm of soft tissue debridement. 


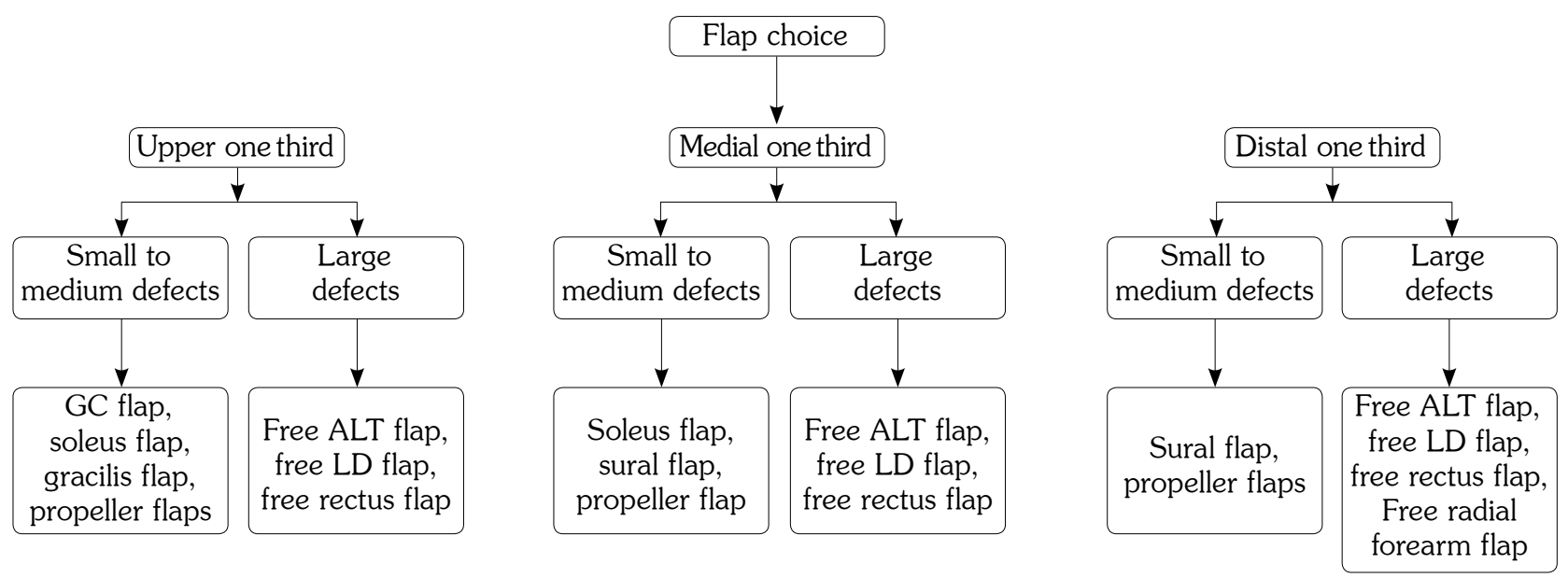

Figure 2. Algorithm of soft tissue reconstruction. GC: Gastrocnemius; ALT: Antero-lateral thigh; LD: Latissimus dorsi.

increases blood flow at the injury site and it helps formation of granulation tissue. Efficacy of VAC treatment in lower extremity injuries has been well documented. ${ }^{[12]}$ Nonetheless, VAC treatment is neither a substitute for debridement nor a definitive reconstruction model, it is just another useful utility in the reconstructive process (Figure 2).

The gastrocnemius muscle is one of the most commonly used pedicled flaps in reconstruction of lower extremities. ${ }^{[14]}$ Soleus can be transposed into wounds of the proximal and middle thirds of the leg ${ }^{[15]}$ The distally based sural flap also has some utility. ${ }^{[16,17]}$ This flap is suitable for covering defects about the one third of distal leg, the heel and the dorsum of the foot.

Another practical option for lower leg soft tissue reconstruction is propellar flap which can be used by the help of one perforator adjacent to the wound ${ }^{[18-21]}$ They are especially useful for covering small to moderate size soft tissue defects in majority of lower extremity. A major advantage may be that they are compatible with the 'replace like with like' concept (Figure 3a-c, Figure 4a-d).

Free flaps may be the only option for large or distal defects. Depending on the need, free flaps can be designed as composite or chimeric flaps. Defect width, three dimensional structure and deficient tissue types (muscle, bone, skin) are the major criteria for composition of free flaps. ${ }^{[22]}$ Free flaps that are frequently used in reconstruction of lower extremity and indications for free flaps in crush lower extremity injury is listed in Table 2. Each flap has its own advantages and indications for use in lower extremity soft tissue replacement.

Latissimus dorsi muscle is large, flat, and has a long vascular pedicle. When a large and wide muscle is necessary for reconstruction, the latissimus dorsi free flap is a suitable option.
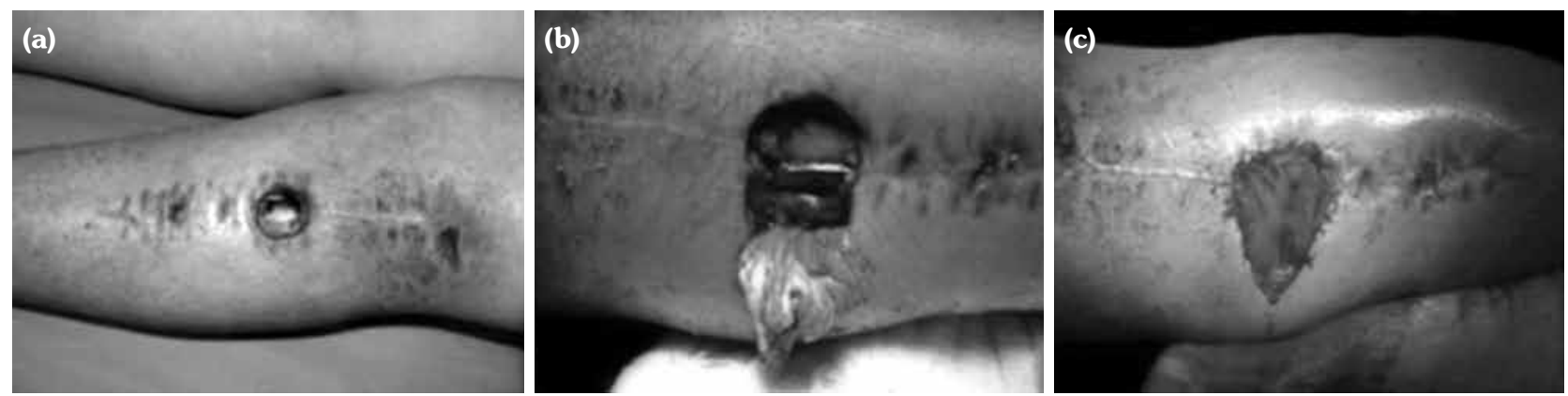

Figure 3. (a-c) Forty-two-year-old female with exposed implant. The defect was reconstructed by using pedicled gastrocnemius flap. 

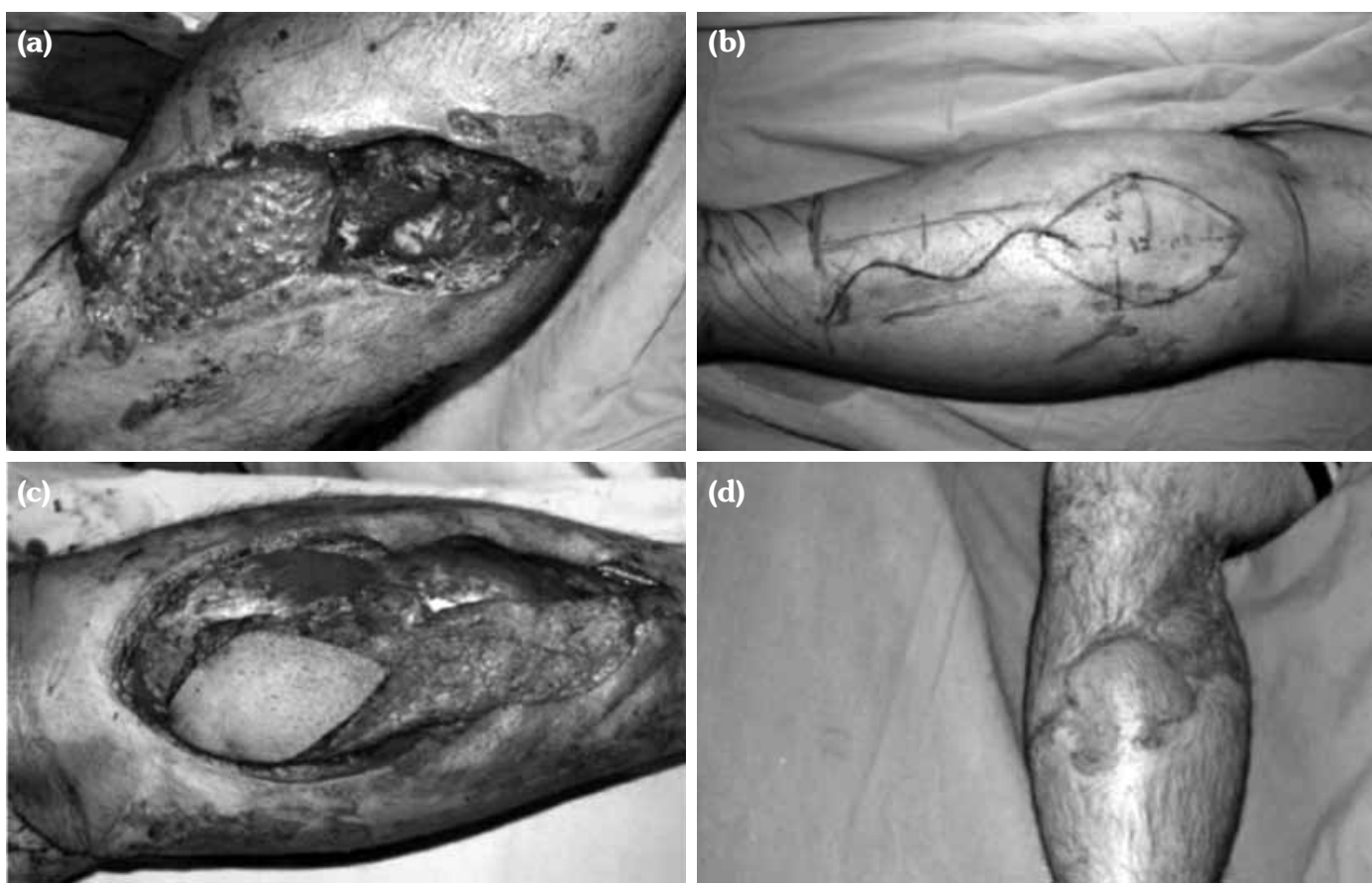

Figure 4. (a) 28-year-old male suffered a work accident. Exposed tibia has been seen after aggressive debridement. (b, c) The defect was reconstructed with pedicled sural flap. (d) An acceptable result was obtained after three months.

Rectus abdominis free flap also has a long pedicle and provides bulky tissue, however it is narrower than the latissimus dorsi.

Main donor site morbidity is abdominal wall weakness. The gracilis flap is a good option for smaller defects and its donor-site morbidity is insignificant. Serafin and Voci ${ }^{[23]}$ recommend the following algorithm for use of free tissue flaps in lower extremity reconstruction: (i) Anastomose the vessels outside the zone of injury, (ii) perform end-to-side arterial anastomoses, (iii) repair the soft tissues first and then restore bone support. The ALT flap is one of the best fascio-cutaneous free flaps for lower limb soft tissue reconstruction. The ALT flap has many advantages: ease of thinning, a

Table 2. Indications for free flap reconstruction for lower extremity tissue defects

\footnotetext{
1. Flow-through free flaps; which may prevent amputations in cases of crush injuries causing soft tissue defect with problems in axial circulation

2. Widely exposed vessels (repairs, grafts or intact vessels)

3. Widely exposed bone, tendon, or nerve

4. Exposed joint

5. Complex tissue defects

6. Major soft tissue defect at the distal third of the leg
}

long vascular pedicle and minimal donor morbidity. There may be some disadvantages such as seldom need for dissection of a musculo-cutaneous perforator and unpleasant scar when donor area is grafted. Free radial forearm flap is another option especially for lower third of leg. Pliability and easy harvesting are major advantages, while donor site scar and sacrifice of the radial artery are the disadvantages (Figure 5a-c, Figure 6a, b).

Richards et al. ${ }^{[24]}$ reported that muscle flaps have blood flow that is three times more than the fasciocutaneous flaps. The authors argued that muscle flaps are more efficient in the coverage of cortical bone. However, many clinical studies have shown success in lower extremity reconstruction with fascia-cutaneous flaps. ${ }^{[25]}$ We usually prefer using either muscle flaps, or fascia-cutaneous flaps in accordance to presence of chronic osteomyelitis. In late reconstruction cases, we advise reconstructing mangled lower limbs with muscle flaps if the bone is infected. In non-complicated cases, fasciocutaneous free flaps may present some advantages over muscle flaps. Some of these are restoration of sensibility and relative ease in secondary revision operations. 

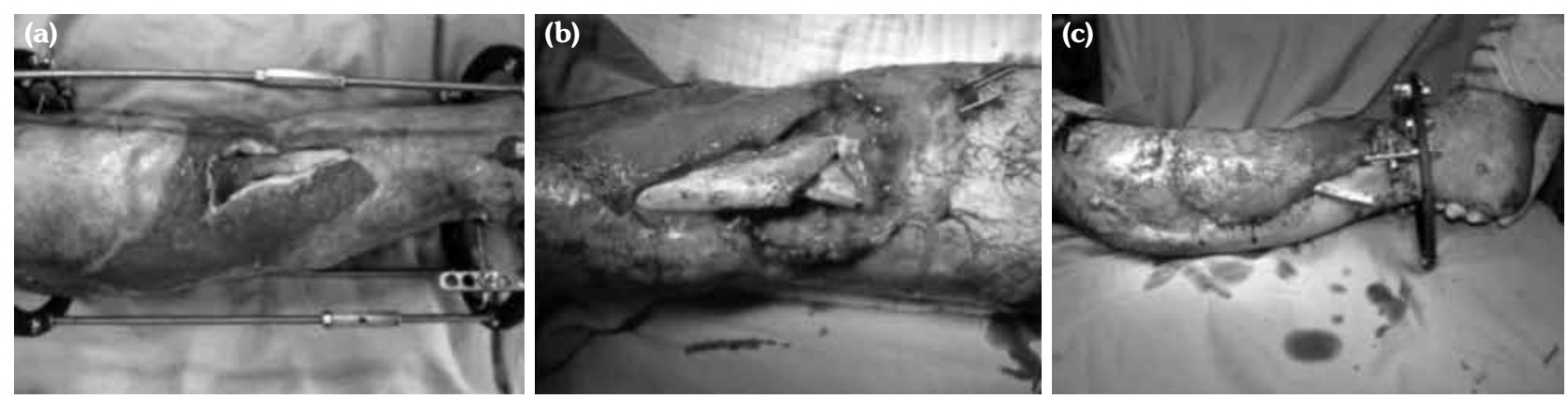

Figure 5. (a) Thirty-eight-year-old male suffered a work accident. He had an oped tibia fracture with pseudomonas infection. (b) Aggressive debridement and revision of fixation has been done by orthopedic surgeon. (c) Wound was covered with free latissimus dorsi flap.

The location of the anatomical region influences the type of flap to be used. For instance, for the proximal one third the gastrocnemius flap is appropriate. For the middle one third pedicled muscle flaps like soleus can be used; albeit in limited ways because of its configuration and circulation. For the distal one third, even for small defects, free flaps are indicated oftenly. For larger defects, latissimus dorsi, ALT flap, rectus abdominis flap, thoraco-dorsal artery perforator flap, radial forearm flap can be used. For small defects, gracilis flap is an important option. We prefer ALT and radial forearm flap in clean wounds, while we prefer latissimus dorsi and rectus flap for contaminated wounds and osteomyelitis. Latissimus dorsi muscle can be bulky at the beginning but it atrophies with time and the contour improves. Distal one third injuries may also be reconstructed with fibula osteocutaneous and latissimus + serratus + rib flaps depending on the reconstructive needs.
One of the main complications in lower extremity reconstruction is venous insufficiency of flaps. At early postoperative period care should be taken for early detection of venous insufficiency. The team should monitor the flap closely. These efforts can prevent flaps from necrosis most of the time. We have experienced venous insufficiency in two free latissimus dorsi flaps. The salvage attempts were successful with early exploration and reanastomoses. We lost one sural flap to venous insufficiency.

Osteomyelitis is a common and troublesome complication for open fractures. In our study, we diagnosed osteomyelitis cases. Studies show that early reconstruction decrease the ratio of

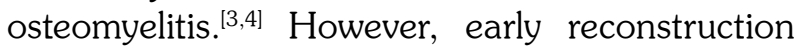
may not always be possible for various reasons.

Our study focused on the soft tissue aspect of reconstruction in mangled lower extremity so management of fractures was not discussed in detail. However it should be emphasized
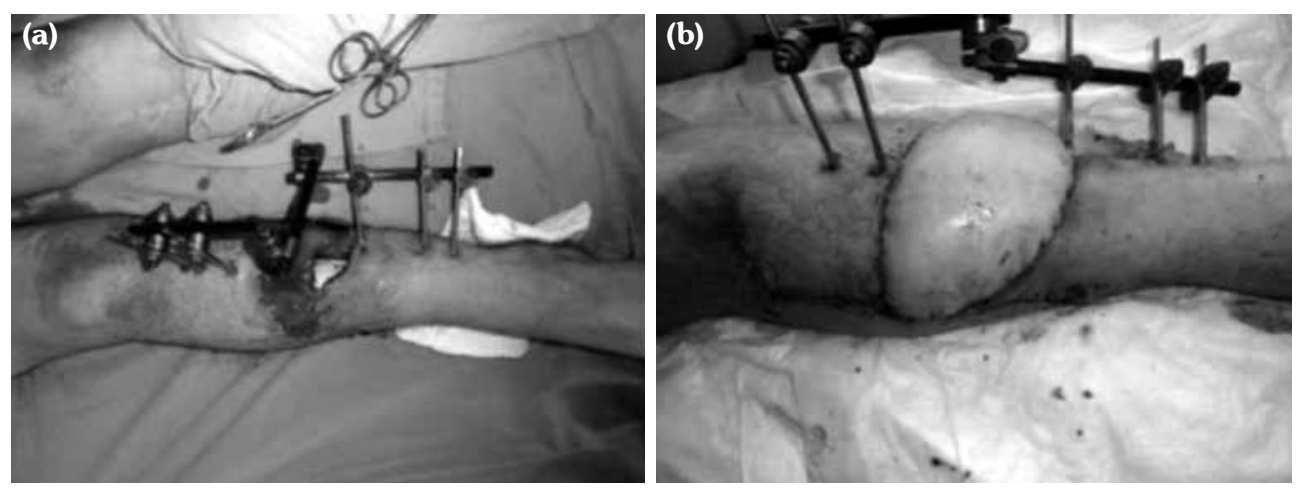

Figure 6. (a) A 22-year-old male suffered a traffic accident. He had an open tibia fracture.

(b) Defect was reconstructed with free antero-lateral thigh flap. 
that external fixators were routinely used in the treatment of Gustillo III-B and C fractures and open-infected bone fractures. The other limitation of the study was its retrospective design.

This retrospective report investigated the outcomes of 81 patients with soft tissue defects who missed the chance of early coverage in an effort to demonstrate our angle in the management of subacute or delayed reconstruction of lower limb. We propose simple algorithms for this purpose. However, the surgeon must customize the reconstructive process for each patient's needs. We believe that post-traumatic reconstruction of mangled lower extremities may also be safely performed in a delayed setting, if the wound is adequately debrided and the basic reconstructive principles are followed.

\section{Declaration of conflicting interests}

The authors declared no conflicts of interest with respect to the authorship and/or publication of this article.

\section{Funding}

The authors received no financial support for the research and/or authorship of this article.

\section{REFERENCES}

1. Prasarn ML, Helfet DL, Kloen P. Management of the mangled extremity. Strategies Trauma Limb Reconstr 2012;7:57-66.

2. Rush RM Jr, Kjorstad R, Starnes BW, Arrington E, Devine JD, Andersen CA. Application of the Mangled Extremity Severity Score in a combat setting. Mil Med 2007;172:777-81.

3. Godina M. Early microsurgical reconstruction of complex trauma of the extremities. Plast Reconstr Surg 1986;78:285-92.

4. Godina M. Early microsurgical reconstruction of complex trauma of the extremities. Plast Reconstr Surg 1986;78:285-92.

5. Byrd HS, Spicer TE, Cierney G. Management of open tibial fractures. Plast Reconstr Surg 1985;76:719-30.

6. Yaremchuk MJ, Brumback RJ, Manson PN, Burgess AR, Poka A, Weiland AJ. Acute and definitive management of traumatic osteocutaneous defects of the lower extremity. Plast Reconstr Surg 1987;80:1-14.

7. Francel TJ, Vander Kolk CA, Hoopes JE, Manson PN, Yaremchuk MJ. Microvascular soft-tissue transplantation for reconstruction of acute open tibial fractures: timing of coverage and long-term functional results. Plast Reconstr Surg 1992;89:478-87.

8. Karanas YL, Nigriny J, Chang J. The timing of microsurgical reconstruction in lower extremity trauma. Microsurgery 2008;28:632-4.
9. Hou Z, Irgit K, Strohecker KA, Matzko ME, Wingert NC, DeSantis JG, et al. Delayed flap reconstruction with vacuum-assisted closure management of the open IIIB tibial fracture. J Trauma 2011;71:1705-8.

10. Tu YK, Lin CH, Su JI, Hsu DT, Chen RJ. Unreamed interlocking nail versus external fixator for open type III tibia fractures. J Trauma 1995;39:361-7.

11. Dorow C, Markgraf E. Therapy of soft tissue injuries-biological strategies. Zentralbl Chir 1997;122:962-9.

12. DeFranzo AJ, Argenta LC, Marks MW, Molnar JA, David LR, Webb LX, et al. The use of vacuum-assisted closure therapy for the treatment of lower-extremity wounds with exposed bone. Plast Reconstr Surg 2001;108:1184-91.

13. Parrett BM, Matros E, Pribaz JJ, Orgill DP. Lower extremity trauma: trends in the management of softtissue reconstruction of open tibia-fibula fractures. Plast Reconstr Surg 2006;117:1315-22.

14. Arnold PG, Mixter RC. Making the most of the gastrocnemius muscles. Plast Reconstr Surg 1983;72:38-48.

15. Tobin GR. Hemisoleus and reversed hemisoleus flaps. Plast Reconstr Surg 1985;76:87-96.

16. Fraccalvieri M, Bogetti P, Verna G, Carlucci S, Fava $\mathrm{R}$, Bruschi S. Distally based fasciocutaneous sural flap for foot reconstruction: a retrospective review of 10 years experience. Foot Ankle Int 2008;29:191-8.

17. Baechler MF, Groth AT, Nesti LJ, Martin BD. Soft tissue management of war wounds to the foot and ankle. Foot Ankle Clin 2010;15:113-38.

18. Hyakusoku H, Yamamoto T, Fumiiri M. The propeller flap method. Br J Plast Surg 1991;44:53-4.

19. Hallock GG. The propeller flap version of the adductor muscle perforator flap for coverage of ischial or trochanteric pressure sores. Ann Plast Surg 2006;56:540-2.

20. Pignatti M, Ogawa R, Hallock GG, Mateev M, Georgescu AV, Balakrishnan G, et al. The "Tokyo" consensus on propeller flaps. Plast Reconstr Surg 2011;127:716-22.

21. Pignatti M, Pasqualini M, Governa M, Bruti M, Rigotti G. Propeller flaps for leg reconstruction. J Plast Reconstr Aesthet Surg 2008;61:777-83.

22. Heller L, Levin LS. Lower extremity microsurgical reconstruction. Plast Reconstr Surg 2001;108:1029-41.

23. Serafin D, Voci VE. Reconstruction of the lower extremity. Microsurgical composite tissue transplantation. Clin Plast Surg 1983;10:55-72.

24. Richards RR, Orsini EC, Mahoney JL, Verschuren R. The influence of muscle flap coverage on the repair of devascularized tibial cortex: an experimental investigation in the dog. Plast Reconstr Surg 1987;79:946-58.

25. Sofiadellis F, Liu DS, Webb A, Macgill K, Rozen WM, Ashton MW. Fasciocutaneous free flaps are more reliable than muscle free flaps in lower limb trauma reconstruction: experience in a single trauma center. J Reconstr Microsurg 2012;28:333-40. 